\title{
Produtividade da couve-flor em função da idade de transplantio das mudas e tamanhos de células na bandeja
}

\author{
Maria Carolina Godoy; Antonio Ismael Inácio Cardoso \\ UNESP - FCA, Depto Produção Vegetal, C. Postal 237, 18603-970 Botucatu-SP; E-mail: ismaeldh@fca.unesp.br
}

\begin{abstract}
RESUMO
O experimento foi realizado de novembro de 2000 a abril de 2001, na UNESP em São Manuel (SP). Estudou-se o efeito do tamanho da célula da bandeja de poliestireno expandido e a idade de transplantio das mudas sobre a produção de couve-flor, híbrido Shiromaru II. Usaram-se bandejas com 128 e 288 células, correspondentes a 34,6 e $9,7 \mathrm{~cm}^{3} /$ célula, respectivamente, e mudas transplantadas aos 27, 34, 41 e 48 dias após a semeadura. Os tratamentos foram arranjados como fatorial $2 \times 4$, dispostos no delineamento de blocos casualizados, com cinco repetições. Foram avaliados, por ocasião do transplantio, o número de folhas, peso fresco, peso seco e área foliar das mudas. A parcela experimental no campo foi constituída por dez plantas. Nas colheitas, avaliaram-se a porcentagem de plantas com cabeça comercial e nestas, o número de folhas, peso fresco e diâmetro da cabeça. A produção total por parcela foi obtida com a soma do peso fresco de todas as cabeças consideradas comerciais. A produção de mudas em bandejas com 128 células proporcionou maior porcentagem de plantas comerciais (64\%) relativamente às bandejas com 288 células (45\%), maior peso médio de cabeça (337 g na bandeja com 128 e 247 g na bandeja com 288 células) e maior produção de plantas comerciais (36,9 t/ha em bandeja de 128 células e 19,9 t/ha em bandeja de 288 células). As mudas transplantadas com 32 dias apresentaram maior peso médio de cabeça (319 g). Concluiu-se ser recomendável produzir mudas de couve-flor em bandejas com 128 células.
\end{abstract}

Palavras-chave: Brassica oleracea var. botrytis, bandeja, volume de célula.

\begin{abstract}
Cauliflower production depending on age of seedling and cell size of the trays

The experiment was carried out from November/2000 to April/ 2001, in São Manuel, São Paulo State, Brazil. The effect of cell size of two polyestyrene trays and age of seedling at transplanting date was observed, on the production of cauliflower, hybrid Shiromaru II. Trays with 128 and 288 cells, corresponding to 34.6 and $9.7 \mathrm{~cm}^{3} /$ cell, respectively, were used with seedlings transplanted at $27 ; 34$; 41 and 48 days after sowing date. The treatments were arranged in a factorial $2 \times 4$, in a randomized block design, with five replication. Leaf number and area, fresh and dry weight of the seedlings at transplanting date was evaluated. The experimental plot was represented by ten plants. The commercial curd production (\%), leaf number, curd weight and diameter were evaluated after harvest. Total yield represents the sum of the fresh weight of all commercial curds. Seedlings produced in 128 cells tray resulted in greater commercial curd percentage (64\%) when compared to trays with 288 cells (45\%), greater curd weight (337 $\mathrm{g}$ and $247 \mathrm{~g}$ when produced in trays with 128 or 288 cells, respectively) and greater total commercial curds (36.9 t/ha and $19.9 \mathrm{t} / \mathrm{ha}$ when produced in 128 or 288 cells trays). Seedlings transplanted 32 days after planting date resulted in plants with the greatest curd weight $(319 \mathrm{~g})$. Based on the obtained results, it is recommended to produce cauliflower seedlings in trays with 128 cells.
\end{abstract}

Keywords: Brassica oleracea var. botrytis, tray, cell size.

(Recebido para publicação em 7 de dezembro de 2003 e aceito em 27 de abril de 2005)

$\mathrm{O}$ uso de bandejas para a produção de mudas de couve-flor (Brassica oleracea var. botrytis L.) cresceu significativamente nos últimos anos pois a maioria dos produtores utiliza sementes híbridas para a safra de verão, de preço muito superior ao das cultivares de polinização aberta (VERDIAL, 2000). As vantagens desse método decorrem do melhor aproveitamento das sementes; da facilidade para a realização dos tratos culturais iniciais (desbaste, capinas, irrigações e pulverizações), diminuindo a possibilidade de falhas; aumento da homogeneidade das plantas; facilidade de transporte; possibilidade de reutilização do material e menores danos às raízes por ocasião do transplantio (MINAMI, 1995; BORNE, 1999). Mu- das de boa qualidade originam plantas com alto potencial produtivo e aquelas com o sistema radicular ou a parte aérea danificados originam plantas com potencial produtivo limitado.

A produção é influenciada pela restrição das raízes e, portanto, pelo tamanho do recipiente (NESMITH; DUVAL, 1998). Maior peso de raízes em recipientes pequenos contribui para a redução do espaço poroso e propicia maior competição por oxigênio. Os recipientes devem ter tamanho que permita a otimização do fornecimento de água, luz e nutrientes até que a muda atinja o tamanho necessário para o transplantio (PEREIRA; MARTINEZ, 1999). As mudas com sistema radicular restrito, quando transplantadas para o campo, têm dificuldade de compensar a evapotranspiração, mesmo se bem irrigadas após o transplantio (WIEN, 1997).

Em repolho, Marsh e Paul (1988) observaram aumento do diâmetro do caule, altura da planta e da área foliar da muda em resposta ao aumento no tamanho do recipiente de produção, mas o material com que era fabricado o recipiente não teve nenhuma influência. Mudas produzidas em bandejas com células de maior tamanho resultaram em plantas com maior peso fresca de cabeça. Mudas de repolho produzidas em bandejas com 7,5 cm de diâmetro de célula, produziram mais precocemente cabeças maiores, comparativamente às produzidas em bandejas com células de 2,5 cm (KRATKY et al., 1982). 
Dufault e Weters (1985) notaram pequeno efeito do tamanho das células das bandejas sobre a produção e o ciclo de couve-brócolos e de couve-flor. Terry et al. (1991) observaram que a produção de couve-brócolos foi antecipada com a utilização de células maiores na produção de mudas; entretanto, não observaram influência significativa da idade das mudas.

A idade da muda é outro fator que pode influenciar a planta no campo, pois seu desenvolvimento radicular é dependente do volume de substrato disponível, e, se for mantida por período muito grande na bandeja, poderá apresentar deficiências nutricionais ou até mesmo enovelamento das raízes. Na produção de couve-flor, como em qualquer outra cultura, imprevistos como chuvas, podem obrigar o produtor a atrasar o transplantio, utilizando mudas velhas. Damato et al. (1994) relataram que a idade da muda não teve influência na aparência comercial da cabeça de couve-brócolos, mas com a utilização de mudas mais velhas houve redução na incidência de talo oco e atraso na maturidade.

Carew e Thompson (1948) atribuíram a produção de cabeça pequena em couve-flor à utilização de mudas velhas, com mais de 42 dias. Também Salter e Fradgley (1969) relataram redução na produção comercial de couve-flor com a utilização de mudas mais velhas.

O tipo e o tamanho de bandejas utilizadas para a produção de mudas é muito variado. Observa-se que existe tendência ao uso de bandejas com células pequenas, uma vez que, quanto menor o volume das células, maior o número de mudas que podem ser obtidas por $\mathrm{m}^{2}$ de estufa além da menor necessidade de substrato e conseqüentemente, menor custo de produção. Entretanto, a economia obtida pode prejudicar a produção final, pois o menor volume de célula pode ser insuficiente para o desenvolvimento adequado das mudas, impedindo que as cultivares disponíveis expressem seu potencial, reduzindo a produtividade e a qualidade da cabeça.

A maioria dos trabalhos relacionados com mudas não são conduzidos até o final do ciclo, sendo interrompidos na fase de transplantio ou, no máximo, até o pegamento das plantas. Daí, a neces- sidade de se estudar a influência do tamanho dos recipientes e idade das mudas sobre a produção. Neste trabalho estudou-se o efeito do tamanho de célula (volume de substrato) e a idade de transplantio das mudas na produtividade da couve-flor.

\section{MATERIAL E MÉTODOS}

O experimento foi realizado em São Manuel (SP), Campus da FCA/UNESP de Botucatu. A temperatura média durante o período experimental foi pouco superior a $20^{\circ} \mathrm{C}$. A temperatura mínima diária oscilou entre 12 e $19,8^{\circ} \mathrm{C}$ e a máxima entre 20 e $33,8^{\circ} \mathrm{C}$.

Foi estudado o híbrido de couve-flor Shiromaru II. Foram produzidas mudas em dois tamanhos de célula da bandeja de poliestireno expandido (128 células, modelo CM 128-62, com 34,6 cm³/célula e 288 células, modelo CM 288-47, com $9,7 \mathrm{~cm}^{3} /$ célula) e quatro idades de transplantio das mudas $(27 ; 34 ; 41$ e 48 dias após a semeadura). Os oito tratamentos resultaram do fatorial $2 \times 4$ e foram arranjados no delineamento experimental de blocos casualizados, com cinco repetições.

Foram feitas quatro semeaduras, semanalmente, a partir de 10/11/2000, visando o transplantio das mudas das quatro idades na mesma data. As bandejas permaneceram em ambiente protegido, em estufa agrícola, com $7 \mathrm{~m}$ de largura, $20 \mathrm{~m}$ de comprimento e pé direito de 2,0 m. As mudas receberam apenas adubação foliar com molibdato de sódio (1 $\mathrm{g} / \mathrm{L}$ ) e ácido bórico (1 g/L), aplicandose aproximadamente $100 \mathrm{ml}$ por bandeja, aos 15 e 22 dias após a semeadura.

Por ocasião do transplantio, foram avaliadas, em cinco plantas de cada parcela, o número de folhas, área foliar e pesos fresco e seco. Em 27/12 foram transplantadas 10 mudas por parcela, no espaçamento de $1,0 \times 0,50 \mathrm{~m}$. A adubação de base, nos canteiros, foi com esterco de galinha $\left(2,5 \mathrm{~L} / \mathrm{m}^{2}\right)$ e adubo mineral 8-28-16 $\left(200 \mathrm{~g} / \mathrm{m}^{2}\right)$. Foram realizadas duas adubações em cobertura, com nitrocálcio, uma aos 15 dias, e outra aos 30 dias após o transplantio, na dose de $5 \mathrm{~g} /$ planta. A irrigação foi por aspersão.
A colheita iniciou em 06/03/2001, totalizando 12 colheitas que se seguiram até o dia 09/04/2001. As cabeças foram colhidas ao se apresentarem bem desenvolvidas, compactas e sem manchas. Foram estimadas a porcentagem de plantas comerciais, referente ao número de plantas totais. Consideraramse não comerciais as que não haviam formado cabeça, as cabeças defeituosas ou aquelas de peso menor de $150 \mathrm{~g}$ (plantas "buttoning"), conforme Pinto e Costa (1977). Das cabeças comerciais, foram avaliados o peso médio obtido sem as folhas externas e com o talo cortado rente à cabeça, a produção total por parcela, o diâmetro transversal e o número de folhas totalmente expandidas.

Os dados obtidos foram submetidos à análise de variância, comparando-se as médias pelo teste de Tukey, ao nível de $5 \%$. Para a característica porcentagem de plantas comerciais, as médias foram transformadas em arcoseno da raiz.

\section{RESULTADOS E DISCUSSÃO}

Observou-se interação significativa entre os fatores idade de transplantio das mudas e volume de célula para a maioria das características avaliadas no momento do transplantio, exceto número de folhas das mudas (Figura 1). O maior desenvolvimento das mudas produzidas nas bandejas de 128 células é um indicativo de que o desenvolvimento da planta é influenciado pelo volume de substrato disponível para ser explorado pelo sistema radicular, o que deve estar associado à disponibilidade de nutrientes para as plantas. A obtenção de mudas mais desenvolvidas ao utilizarem-se recipientes com maior volume de substrato foi verificada também em berinjela (BARNABÉ et al., 1994a), beterraba (ECHER et al., 2000), pimentão (BARNABÉ et al., 1994b), repolho (MARSH; PAUL, 1988) e tomate (BARROS et al., 1997). Segundo Pereira e Martinez (1999), isto pode ser atribuído ao fato de as mudas produzidas em recipientes de maior volume não apresentarem restrição ao crescimento radicular, otimizando, desta forma, o fornecimento de nutrientes, água e luz, favorecendo a maior expansão das folhas.

A regressão de segundo grau se adequou às características peso fresco e 
Tabela 1. Peso fresco da cabeça $(\mathrm{g})$, número de folhas por planta, diâmetro da cabeça $(\mathrm{cm})$, produção total $(\mathrm{t} / \mathrm{ha})$ e cabeças comerciais $(\%)$ de couve-flor, por ocasião da colheita das plantas, em função do tipo de bandeja. São Manuel, UNESP, 2001.

\begin{tabular}{lccccc}
\hline Bandeja & $\begin{array}{c}\text { Peso fresco } \\
\text { da cabeça } \\
\text { (g) }\end{array}$ & $\begin{array}{c}\text { Número de } \\
\text { folhas/planta }\end{array}$ & $\begin{array}{c}\text { Diâmetro da } \\
\text { cabeça } \\
\text { (cm) }\end{array}$ & $\begin{array}{c}\text { Produção } \\
\text { total } \\
\text { (t/ha) }\end{array}$ & $\begin{array}{c}\text { Cabeças } \\
\text { comerciais } \\
\text { (\%) }\end{array}$ \\
\hline 128 & $337 \mathrm{a}^{1}$ & $22,4 \mathrm{a}$ & $13,7 \mathrm{a}$ & $36,9 \mathrm{a}$ & $64,3 \mathrm{a}$ \\
288 & $247 \mathrm{~b}$ & $20,9 \mathrm{~b}$ & $11,5 \mathrm{~b}$ & $19,9 \mathrm{~b}$ & $45,3 \mathrm{~b}$ \\
\hline $\mathrm{CV} \%$ & 22,0 & 7,1 & 18,1 & 24,2 & 37,3 \\
\hline
\end{tabular}

Médias seguidas pela mesma letra, nas colunas, não diferem estatisticamente pelo teste $\mathrm{F}$, a $5 \%$ de probabilidade.
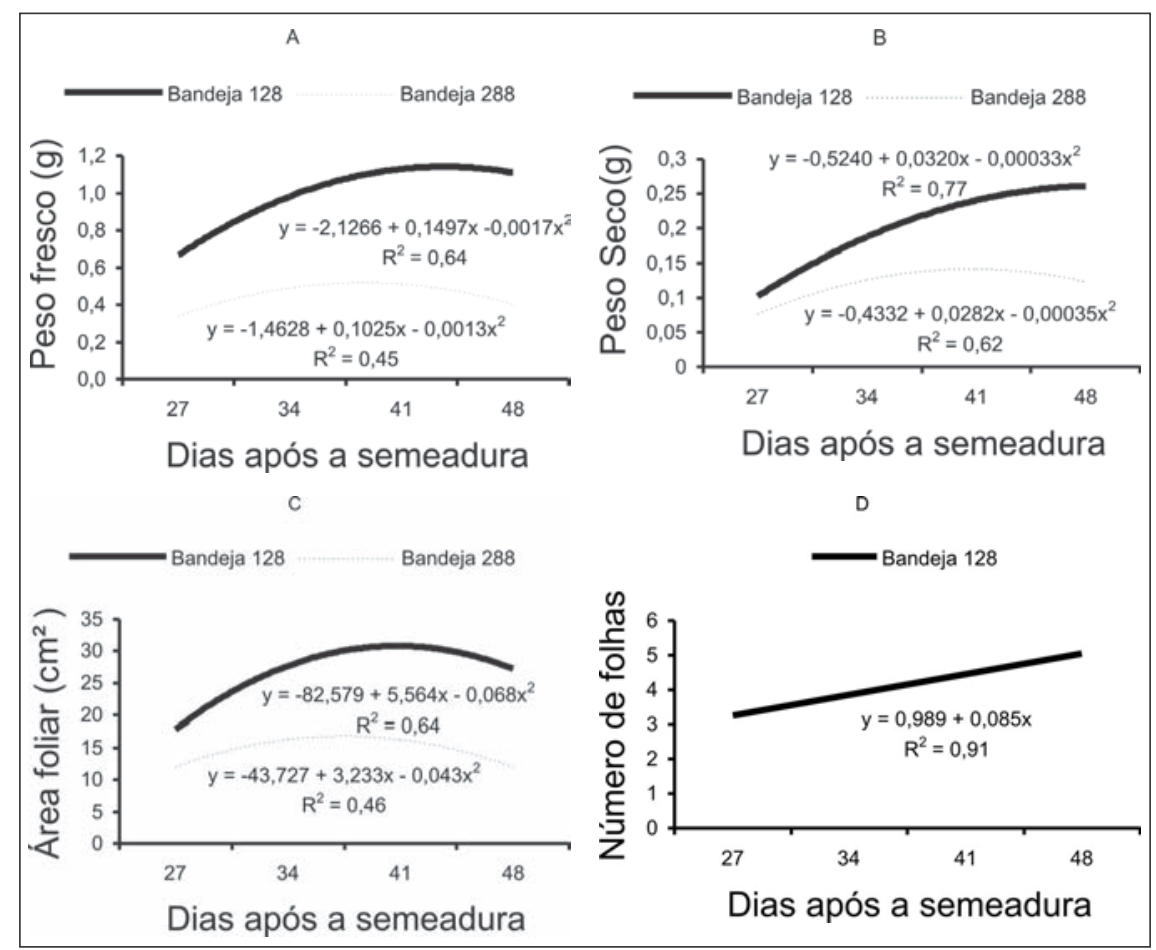

Figura 1. Peso fresco (A), peso seco (B), área foliar (C) e número de folhas (D) das mudas, por ocasião do transplantio, em função do tamanho da célula da bandeja e da idade de transplantio das mudas. São Manuel, UNESP, 2001.

seco e área foliar, independente da bandeja utilizada, enquanto que para número de folhas obteve-se um aumento linear apenas na bandeja com 128 células (Figura 1). Já a bandeja com 288 células não afetou o número de folhas, com uma média de 3,3 folhas por muda, independente da idade. Com exceção do número de folhas, onde não se observou interação significativa, observa-se que a diferença entre as mudas obtidas nas duas bandejas é pequena nas mudas mais novas e aumenta com a idade das mudas. Na bandeja de 128 células estima-se um máximo de peso fresco, seco e área foliar aos 44, 48 e 41 dias, respectivamente. Já na bandeja de 288 cé- terísticas de produção avaliadas ao final do ciclo. Liu e Latimer (1995) e Jones et al. (1991) também obtiveram aumento significativo na produção de melancia e em repolho, quando as mudas foram produzidas em recipientes com maior volume da célula.

Observou-se aumento na porcentagem de plantas comerciais com aumento na idade das mudas, com um máximo aos 41 dias (Figura 2). Aparentemente, as mudas mais novas, por serem de menor tamanho, foram influenciadas pelas chuvas fortes, que ocorreram no primeiro mês após o transplantio $(771,4$ $\mathrm{mm}$, em 30 dias). Esse resultado contrasta com o relatado por Carew e Thompson (1948), que verificaram maior incidência de plantas não comerciais a partir de mudas mais velhas, com mais de 42 dias. Também Skapsky e Oyer (1964) relataram maior porcentagem de plantas com cabeça não comercial, ao transplantarem mudas muito grandes, com mais de $5 \mathrm{~g}$ de peso fresco, o que superou bastante o peso médio das mudas maiores deste experimento, de apenas 1,2 g. Aqueles autores sugerem que não seja utilizada a idade cronológica da muda como parâmetro para o estudo da porcentagem de plantas "buttoning", mas sim o estádio de desenvolvimento medido pelo número de folhas, uma vez que fatores ambientais influenciam o crescimento das mudas.

O número de folhas por planta, o diâmetro da cabeça e a produção total não foram influenciados pela idade de transplantio da muda. $\mathrm{O}$ valor máximo estimado para peso médio de cabeça (319 g) foi para mudas com 32 dias (Figura 2), com acentuado decréscimo no peso médio nas mudas mais velhas. Pode ser resultado do esgotamento dos nutrientes do substrato e conseqüentes deficiências nutricionais nas mudas mais velhas que já se apresentavam amareladas ao serem transplantadas. A redução no peso médio de cabeça com mudas mais velhas também foi relatado por Carew e Thompson (1948), que obtiveram redução de até $50 \%$ no peso da cabeça com a utilização de mudas velhas (8 a 10 semanas), comparado às novas (4 a 6 semanas). No presente trabalho, as mudas mais velhas apresentavam quase 7 semanas, porém, a tendên- 
cia observada foi de decréscimo no peso médio de cabeça já a partir de 32 dias. Salter e Fradgley (1969) também relataram redução na produção comercial de couve-flor com a utilização de mudas mais velhas.

Conforme sugerido por Skapsky e Oyer (1964), deve-se relacionar a idade cronológica ao estádio de desenvolvimento da muda. Assim, mudas com 32 dias já haviam emitido a quarta folha definitiva, quando cultivadas na bandeja de 128 células (Figura 1) e essas resultaram em maior peso de cabeça e produção total. Portanto, para as condições em que foi realizado o experimento, pode-se recomendar a utilização de bandejas com 128 células $\left(34,6 \mathrm{~cm}^{3} /\right.$ célula) e a realização do transplante quando as mudas apresentarem 32 dias.

\section{AGRADECIMENTOS}

Os autores agradecem à FAPESP, pela concessão da bolsa de Iniciação Científica à primeira autora (Processo 00/06180-0).

\section{LITERATURA CITADA}

BARNABÉ, F.A.; GIORGETTI, J.R.; GOTO. R Influência de três tipos de bandejas, para a produção de mudas de berinjela. Horticultura Brasileira, Brasília, v.18, suplemento, p.71, 1994a. BARNABÉ, F.A.; GIORGETTI, J.R. GOTO.; R Influência de três tipos de bandejas, para a produção de mudas de pimentão. Horticultura Brasileira, Brasília, v.18, suplemento, p.71, 1994b. BARROS, S.B.M.; TESSARIOLI NETO, J.; MINAMI, K., GRANJA, N.P. Avaliação de diferentes recipientes para a produção de mudas de tomate (Lycopersicon esculentum Mill.). In: CONGRESSO BRASILEIRO DE OLERICULTURA 37, Manaus. Resumos... Brasília: SOB, 1997. p.239.

BORNE, H.R. Produção de mudas de hortaliças. Guaíba: Agopecuária, 1999. 187 p.

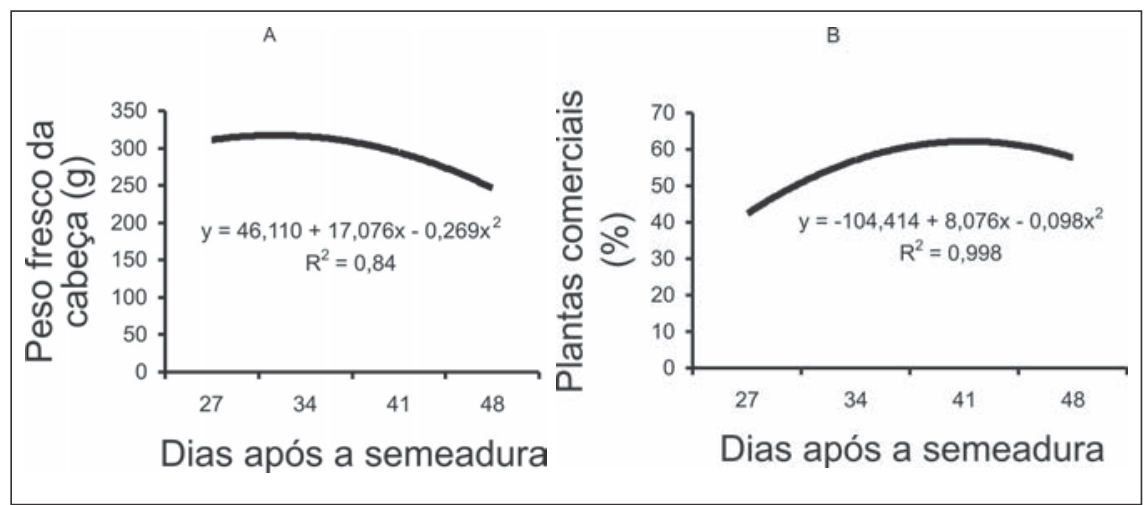

Figura 2. Peso fresco da cabeça (A) e proporção de plantas comerciais (B) em função da idade de transplantio das mudas. São Manuel, UNESP, 2001.

CAREW, J.; THOMPSOM, H.C. A study of certain factors affecting "buttoning" of cauliflower. Proceedings of American Society for Horticutural Science, v.51, p.406-414, 1948.

DAMATO, G.; TROTTA, L.; ELIA, A. Cell size, transplant age and cultivars effects on timing field production of broccoli (Brassica oleraceae L. var. italica Plenck) for processing. Acta Horticulturae, n.371, p.53-57, 1994.

DUFAULT, R.J.; WETERS, L. Jr. Container size influences broccoli and cauliflower transplant growth but not yield. HortScience, v.20, p.682-684, 1985. ECHER, M.M.; ARANDA, A.N.; BORTOLAZZO, ED.; BRAGA, J.S.; TESSARIOLI NETO, J. Efeito de três substratos e dois recipientes na produção de mudas de beterraba. Horticultura Brasileira, Brasília, v.18, suplemento, p.509-510, 2000.

JONES, R.T.; WESTON, L.A.; HARMON, R. Effect of root cell size and transplant age on cole crop yields. HortScience, v.26, p.688, 1991.

KRATKY, B.A.; WANG, J. K.; KUBOJIRI, K. Effects of container size, transplant age, and plant spacing on chinese cabbage. Journal of American Society for Horticultural Science, v.107, p.345347, 1982.

LIU, A.; LATIMER, J.G. Root cell volume in the planter flat affects watermelon seedling development and fruit yield. HortScience, v.30, p.242-246, 1995.

MARSH.; D.; PAUL, K.B. Influence of container type and cell size on cabbage transplant and field performance. HortScience, v.23, p.310-311, 1988. MINAMI, K. Produção de mudas de alta qualidade em horticultura. São Paulo: T.A. Queiroz, 1995. $128 \mathrm{p}$.
NESMITH, D.S.; DUVAL, J.R. The effect of container size. HortTecnology, v.8, n.4, p.495-498, 1998. PEREIRA, P.R.G.; MARTINEZ, H.E.P. Produção de mudas para o cultivo de hortaliças em solo e hidroponia. Informe Agropecuário, Belo Horizonte, v.20, n.200/201, p.24-31, 1999.

PINTO, C.A.B.P.; COSTA, C.P. Melhoramento de hortaliças. Piracicaba: Dep. de Genética ESALQ/ USP, 1977. (Apostila)

SALTER, P.J.; FRADGLEY, J.R.A. Studies on crop maturity in cauliflower II. Effects of cultural factors on the maturity characteristcs of a cauliflower. Journal of Horticultural Science, v.44, n.3, p.265-272, 1969.

SKAPSKI, H.; OYER, E.B. The influence of pretransplanting variables on the growth and development of cauliflower plants. Proceedings of American Society for Horticultural Science, v.85, p.374-385. 1964.

TERRY, J.R.; WESTON, L.A.; HARMON, R. Effect of root cell size and transplant age on cole crop yields. HortScience, v.26, p.688, 1991.

VERDIAL, M.F. Influência da coincidência de florescimento entre linhagens de couve-flor (Brassica oleracea var. botrytis) na produtividade e qualidade de sementes híbridas. Botucatu, 2000. 56 f. Dissertação (Mestrado em Agronomia, área de concentração em Horticultura) - Faculdade de Ciências Agronômicas, UNESP, Botucatu. WIEBE, H.J. Influence of transplant characteristics and growing conditions on curd size (buttoning) of cauliflower. Acta Horticulturae, n.122, p.99-105, 1981.

WIEN, H.C. The physiology of vegetable crops. Oxon: CABI Publishing, 1997. 662 p. 